\title{
Variation in genes encoding eosinophil granule proteins in atopic dermatitis patients from Germany

\author{
Qumar Parwez ${ }^{1}$, Susanne Stemmler*2, Jörg T Epplen ${ }^{2}$ and Sabine Hoffjan ${ }^{2}$
}

Address: ${ }^{1}$ Private medical practice, Gladbeck, Germany and 2Department of Human Genetics, Ruhr-University, Bochum, Germany

Email: Qumar Parwez - qumar.parwez@t-online.de; Susanne Stemmler* - susanne.stemmler@rub.de; Jörg T Epplen - joerg.t.epplen@rub.de;

Sabine Hoffjan - Sabine.Hoffjan@ruhr-uni-bochum.de

* Corresponding author

Published: 13 November 2008

Journal of Negative Results in BioMedicine 2008, 7:9 doi:10.1 186/1477-575I-7-9

This article is available from: http://www.jnrbm.com/content/7/I/9

(C) 2008 Parwez et al; licensee BioMed Central Ltd.

This is an Open Access article distributed under the terms of the Creative Commons Attribution License (http://creativecommons.org/licenses/by/2.0), which permits unrestricted use, distribution, and reproduction in any medium, provided the original work is properly cited.

\begin{abstract}
Background: Atopic dermatitis (AD) is believed to result from complex interactions between genetic and environmental factors. A main feature of $A D$ as well as other allergic disorders is serum and tissue eosinophilia. Human eosinophils contain high amounts of cationic granule proteins, including eosinophil cationic protein (ECP), eosinophil-derived neurotoxin (EDN), eosinophil peroxidase (EPO) and major basic protein (MBP). Recently, variation in genes encoding eosinophil granule proteins has been suggested to play a role in the pathogenesis of allergic disorders. We therefore genotyped selected single nucleotide polymorphisms within the ECP, EDN, EPO and MBP genes in a cohort of $36 \mathrm{I}$ German AD patients and 325 healthy controls.
\end{abstract}

Results: Genotype and allele frequencies did not differ between patients and controls for all polymorphisms investigated in this study. Haplotype analysis did not reveal any additional information.

Conclusion: We did not find evidence to support an influence of variation in genes encoding eosinophil granule proteins for AD pathogenesis in this German cohort.

\section{Background}

Atopic dermatitis (AD) is a chronic inflammatory skin disease believed to arise from complex interactions between genetic and environmental factors [1]. AD belongs to the group of allergic disorders, also including allergic asthma, allergic rhinitis and food allergy. As a main feature of allergic disorders, $\mathrm{AD}$ is often accompanied by eosinophilia [2]. Human eosinophils contain high amounts of cationic granule proteins, including eosinophil cationic protein (ECP), eosinophil-derived neurotoxin (EDN), eosinophil peroxidase (EPO) and major basic protein (MBP). Eosinophil degranulation with deposition of these proteins in the skin has been shown to play an important role in $\mathrm{AD}$ [2]. Furthermore, serum and urine concentrations of eosinophil proteins are indirect measures of inflammatory activity in AD. For example, several studies have confirmed that urine EDN (also called EPX) is a useful in vitro parameter of inflammation in $\mathrm{AD}$ [3-5]. Measurement of ECP levels in serum also is a frequently used tool in monitoring $\mathrm{AD}$ activity $[4,6]$.

Recently, variation in genes encoding eosinophil granule proteins has been suggested as potential factor in the pathogenesis of allergic disorders. In particular, a nonsynonymous polymorphism in the ECP gene was associated with allergic symptoms [7], and a polymorphism in the 3'UTR of this gene showed correlation with the cellular content of ECP [8]. More recently, ECP haplotypes 
were found associated with asthma and serum ECP levels [9]. Variation in the EDN gene was evaluated for an association with tropical pulmonary eosinophilia but did not show an association with this disease in a small cohort [10].

Since eosinophil degranulation seems to play an important role in $\mathrm{AD}$, we speculated that variation in genes encoding eosinophil granule proteins might show an association with $\mathrm{AD}$. We therefore genotyped selected single nucleotide polymorphisms (SNPs) within the ECP, $E D N, E P O$ and $M B P$ genes in a cohort of 361 German $A D$ patients and 325 healthy controls.

\section{Methods \\ Subjects}

361 unrelated patients with $\mathrm{AD}$, including 217 children and 144 adults, were recruited by a consultant specialist for AD (Q.P., Gladbeck, Germany). Mean age of the AD patients was $18 \pm 7$ years. The AD diagnosis was based on the criteria developed by Hanifin and Rajka [11]. 325 control samples from adults of at least 40 years of age without known allergies, asthma or $\mathrm{AD}$ were collected in the same private practice as the $\mathrm{AD}$ patients. Mean age of the controls was $57 \pm 13$ years. We specifically chose to use nonallergic adults as controls because the risk remains very high for primarily asymptomatic children to develop an allergic disease during childhood or even adulthood $[12,13]$. The control subjects underwent clinical examination in order to exclude symptoms of $\mathrm{AD}$, asthma or allergic rhinitis. They further reported to have no allergic symptoms and no first degree relatives with known allergic diseases. All patients and control subjects were Germans of European origin. Informed consent was obtained from all subjects. The study was approved by the Ethics Committee of the University of Bochum, and the Declaration of Helsinki protocols were followed.

\section{Genotyping}

Genotyping for all polymorphisms was performed by polymerase chain reaction (PCR) with subsequent restriction enzyme digestion. Details for PCR conditions and restriction enzymes are summarized in table 1 . PCR reactions were performed in a total volume of $10 \mu \mathrm{l}$, containing $45 \mathrm{ng}$ DNA, $2 \mathrm{mM}$ of each dNTP, $1-3 \mathrm{mmol} \mathrm{MgCl}_{2}, 5$ pmol of the respective forward and reverse primer and 0.4 U Taq polymerase (Ares Bioscience, Lüdinghausen, Germany) on a Biometra Thermal Cycler (Göttingen, Germany). The PCR products were digested with the respective enzyme (table $1,0.01 \mathrm{U} / \mathrm{ng} \mathrm{DNA}$ ) at $37^{\circ} \mathrm{C}$ for three hours. The fragments were subsequently separated on $2.5-3.5 \%$ agarose gels in $1 \times$ TBE buffer ( $30 \mathrm{~min}, 200 \mathrm{~V}$ ) and visualized using ethidium bromide staining.

Table I: Polymorphisms typed in the EDN, ECP, EPO and MBP genes.

\begin{tabular}{|c|c|c|c|c|c|c|}
\hline Gene & Rs number & Location & Amino acid & Primer & Annealing temperature & Restriction enzyme \\
\hline EDN & rs2013109 & Intron I & - & $\begin{array}{l}\text { F: GGGTAAGTCAACGATCCCCAG } \\
\text { R: } \\
\text { GGTCTTGGTTATGACACACACTGT } \\
\text { AGT }\end{array}$ & $69^{\circ} \mathrm{C}$ & HpyFIOVI \\
\hline EDN & rs 10132319 & Intron I & - & $\begin{array}{l}\text { F: GGGTAAGTCAACGATCCCCAG } \\
\text { R: } \\
\text { GGTCTTGGTTATGACACACACTGT } \\
\text { AGT }\end{array}$ & $65^{\circ} \mathrm{C}$ & Acil \\
\hline$E C P$ & rs I779248I & Intron I & - & $\begin{array}{l}\text { F: TGAGGGAGAGGTGAGCTGAAGT } \\
\text { R: TGATGTGCTGGATGGCAAAC }\end{array}$ & $58^{\circ} \mathrm{C}$ & Mbol \\
\hline$E C P$ & rs2073342 & Exon 2 & $\mathrm{TI} 24 \mathrm{R}$ & $\begin{array}{l}\text { F: TACGCTGCCCTCATAACAGAACT } \\
\text { R: GAACTGGAACCACAGGATACCG }\end{array}$ & $58^{\circ} \mathrm{C}$ & Pstl \\
\hline$E C P$ & rs2233860 & 3' UTR & - & $\begin{array}{l}\text { F: } \\
\text { GTATGCAGACAGACCAGGAAGGA } \\
\text { R: } \\
\text { TTGGCAGATGAGTGATGATGAGTA }\end{array}$ & $61^{\circ} \mathrm{C}$ & Rsal \\
\hline EPO & rs II652709 & Exon 4 & $\mathrm{Q} 122 \mathrm{H}$ & $\begin{array}{l}\text { F: CTACCCTGGCCTGGAGTAGAAG } \\
\text { R: CACGCACTTGTTGTTGCACC }\end{array}$ & $64^{\circ} \mathrm{C}$ & HpyFIOVI \\
\hline EPO & rs3785496 & Intron 6 & - & $\begin{array}{l}\text { F: ACTGGTTGTCACTTCCССTCTC } \\
\text { R: } \\
\text { CAAAACCTTGCTTAAAACTCССTT }\end{array}$ & $58^{\circ} \mathrm{C}$ & Msel \\
\hline MBP & rs490358 & Exon 2 & - & $\begin{array}{l}\text { F: } \\
\text { GGAAAAAACAGAGAAAGAAAGACT } \\
\text { GAA } \\
\text { R: CACTCCCACGGTCCCCTAAT }\end{array}$ & $58^{\circ} \mathrm{C}$ & Bsll \\
\hline MBP & rs3741098 & Intron 3 & - & $\begin{array}{l}\text { F: } \\
\text { TGGTGGACAAAAACCTTACGTGTC } \\
\text { R: ATGCTGGGGGCATATCCGA }\end{array}$ & $58^{\circ} \mathrm{C}$ & BsaHI \\
\hline
\end{tabular}




\section{Statistical analyses}

Genotype and allele frequencies were ascertained by direct counting and subsequently analyzed according to the $\chi^{2}$ method. Deviations from Hardy-Weinberg equilibrium were evaluated using the DeFinetti program [14]. P $<0.05$ was considered to be significant. Haplotype frequencies were estimated using the Haploview software and compared between cases and controls using a contingency $\chi^{2}$ test. We performed power analyses with the Genetic Power Calculator program [15].

\section{Results}

We genotyped a total of nine SNPs in four genes encoding eosinophil granule proteins (table 1). rs10132319 in intron 1 of the EDN gene turned out to be monomorphic in our cohort and thus was excluded from further analysis. All other SNPs were in Hardy-Weinberg equilibrium in cases and controls. None of the polymorphisms investigated here showed an association with AD in our cohort (table 2). Power analyses performed with the Genetic Power Calculator program [15] revealed, that given a mul- tiplicative model with a genotypic relative risk of 2 for heterozygotes and 4 for homozygotes and a D' of 0.9 , we have $89 \%$ power to detect a potential effect. Choosing more conservative parameters with a genotypic relative risk of $1.5 / 2.25$ and $D^{\prime}$ of 0.8 , would yield only $33 \%$ power.

Haplotype analyses in the ECP gene revealed four different haplotypes with a frequency above 1\%: A-G-G, C-G-G, $\mathrm{C}-\mathrm{C}-\mathrm{C}$ and $\mathrm{C}-\mathrm{C}-\mathrm{G}$, as described before [9]. Haplotype frequencies did not differ between $\mathrm{AD}$ patients and controls (table 3).

\section{Discussion}

In the present study, we did not find evidence to support an influence of variation in genes encoding eosinophil granule proteins for $\mathrm{AD}$ pathogenesis in a thoroughly characterized German cohort.

In the ECP gene, the three polymorphisms were evaluated that had shown association to allergic phenotypes either

Table 2: Genotype frequencies of EDN, ECP, EPO and MBP polymorphisms in AD patients and controls.

\begin{tabular}{|c|c|c|c|c|c|}
\hline Gene & Polymorphism & Genotypes & AD patients & controls & p-value \\
\hline \multirow[t]{4}{*}{ EDN } & rs2013109 & $\mathrm{C} / \mathrm{C}$ & $22(6.1 \%)$ & $23(7.1 \%)$ & 0.66 \\
\hline & & $\mathrm{C} / \mathrm{G}$ & $148(41.0 \%)$ & $123(37.8 \%)$ & \\
\hline & & $\mathrm{G} / \mathrm{G}$ & 191 (52.9\%) & 179 (55.1\%) & \\
\hline & rs 10132319 & Not polymorphic & - & - & - \\
\hline \multirow[t]{9}{*}{$E C P$} & rs2073342 & $\mathrm{A} / \mathrm{A}$ & $53(14.7 \%)$ & $57(17.6 \%)$ & 0.45 \\
\hline & & $\mathrm{A} / \mathrm{C}$ & 185 (5I.2\%) & $152(47.1 \%)$ & \\
\hline & & $\mathrm{C} / \mathrm{C}$ & $123(34.1 \%)$ & 114 (35.3\%) & \\
\hline & rs2073342 & $\mathrm{C} / \mathrm{C}$ & 26 (7.2\%) & 32 (9.8\%) & 0.13 \\
\hline & & $C / G$ & $158(43.9 \%)$ & $120(36.9 \%)$ & \\
\hline & & $\mathrm{G} / \mathrm{G}$ & 176 (48.9\%) & $173(53.2 \%)$ & \\
\hline & rs2233860 & $\mathrm{C} / \mathrm{C}$ & 15 (4.1\%) & $19(5.9 \%)$ & 0.55 \\
\hline & & $C / G$ & $123(34.1 \%)$ & $104(32.1 \%)$ & \\
\hline & & $\mathrm{G} / \mathrm{G}$ & $223(61.8 \%)$ & 201 (62.0\%) & \\
\hline \multirow[t]{6}{*}{ EPO } & rs II652709 & $\mathrm{C} / \mathrm{C}$ & 34 (9.4\%) & 35 (10.8\%) & 0.42 \\
\hline & & $\mathrm{C} / \mathrm{G}$ & $170(47.2 \%)$ & $137(42.3 \%)$ & \\
\hline & & $\mathrm{G} / \mathrm{G}$ & I 56 (43.3\%) & I52 (46.9\%) & \\
\hline & rs3785496 & $\mathrm{G} / \mathrm{G}$ & $23(6.4 \%)$ & I 8 (5.6\%) & 0.89 \\
\hline & & $\mathrm{G} / \mathrm{A}$ & $142(39.4 \%)$ & $130(40.1 \%)$ & \\
\hline & & $\mathrm{A} / \mathrm{A}$ & 195 (54.2\%) & 176 (54.3\%) & \\
\hline \multirow[t]{6}{*}{$M B P$} & rs490358 & $\mathrm{A} / \mathrm{A}$ & 29 (8.0\%) & 27 (8.3\%) & 0.98 \\
\hline & & $\mathrm{A} / \mathrm{G}$ & $137(38.0 \%)$ & 121 (37.2\%) & \\
\hline & & G/G & 195 (54.0\%) & 177 (54.5\%) & \\
\hline & rs3741089 & $\mathrm{T} / \mathrm{T}$ & 99 (27.6\%) & 99 (30.7\%) & 0.66 \\
\hline & & $\mathrm{T} / \mathrm{C}$ & 184 (5I.2\%) & $158(49.1 \%)$ & \\
\hline & & $\mathrm{C} / \mathrm{C}$ & $76(21.2 \%)$ & 65 (20.2\%) & \\
\hline
\end{tabular}


Table 3: Frequencies and $p$-values of ECP haplotypes in AD patients and controls.

\begin{tabular}{cccc}
\hline Haplotype & Frequency in AD patients $(\mathbf{n = 3 6} \mathbf{~})$ & Frequency in controls $(\mathbf{n}=\mathbf{3 2 5})$ & $\mathbf{p - v a l u e}$ \\
\hline A-G-G & 0.401 & 0.408 & 0.762 \\
C-G-G & 0.305 & 0.304 & 0.934 \\
C-C-C & 0.209 & 0.214 & 0.830 \\
C-C-G & 0.080 & 0.070 & 0.439 \\
\hline
\end{tabular}

in single SNP [7] or haplotype analysis [9] in previous studies. Genotype as well as haplotype frequencies in our cohort were very similar to the frequencies reported in these other studies, but did not differ between AD patients and controls. Thus, our results seem to contradict these earlier reports. Yet, none of the preceding studies specifically addressed the phenotype $\mathrm{AD}$, but rather allergic symptoms in general [7] or allergic asthma [9]. Linkage studies have shown that there is surprisingly little overlap between the main susceptibility regions for asthma and $\mathrm{AD}$, even though both diseases belong to the group of allergic disorders [16]. Thus, it is possible that ECP variation might influence the development of (allergic) asthma but have no measurable influence on $\mathrm{AD}$ development. Furthermore, the association of the ECP T124R SNP with allergic symptoms was demonstrated in a very small cohort (209 medical students and 76 asthmatic patients) [7], and it still remains to be investigated whether this association will hold true in a larger cohort of allergic patients. Clearly, additional studies in sufficiently large cohorts of patients with allergy, asthma and $\mathrm{AD}$ are needed to further elucidate the role of variation in this gene for the various allergic diseases.

For the other three genes evaluated in this study, no association studies for $\mathrm{AD}$ or asthma have been published so far. Only the EDN gene (together with ECP) was evaluated for an association with tropical pulmonary eosinophilia but did not show an association with this disease in a small cohort [10]. We nevertheless speculated that they might constitute interesting candidate genes for $\mathrm{AD}$ since eosinophil degranulation with deposition of all of these proteins in the skin has been shown to play an important role in $\mathrm{AD}$ [2]. Furthermore, several studies have confirmed that urine EDN is a useful in vitro parameter of inflammation in $\mathrm{AD}$ [3-5]. Interestingly, the EPO gene is located on chromosome $17 \mathrm{q} 23$, close to the regions of highest linkage to $\mathrm{AD}$ or $\mathrm{AD}$ severity in two genome-wide screens $[17,18]$. Yet, none of the investigated polymorphisms in these genes showed differences in allele, genotype or haplotype distribution between $\mathrm{AD}$ patients and controls in our cohorts, suggesting that they may probably not play an important role in $\mathrm{AD}$ pathogenesis.

\section{Conclusion}

We did not find evidence to support an influence of variation in genes encoding eosinophil granule proteins for $\mathrm{AD}$ pathogenesis in this German cohort. However, we cannot exclude a contribution of variation in these genes entirely. Additional association studies as well as functional assessment of the investigated polymorphisms might further elucidate their role in allergic diseases.

\section{Abbreviations}

AD: atopic dermatitis; ECP: eosinophil cationic protein; EDN: eosinophil derived neurotoxin; EPO: eosinophil peroxidase; MBP: major basic protein; PCR: polymerase chain reaction

\section{Competing interests}

The authors declare that they have no competing interests.

\section{Authors' contributions}

QP recruited the patients and control subjects, collected clinical data, performed the experiments and drafted the manuscript. SS and JTE participated in the design and coordination of the study. SH was in charge of the design and coordination of the study as well as the statistical analyses and finalised the manuscript. All authors read and approved the final manuscript.

\section{Acknowledgements}

We thank Daniela Falkenstein for technical assistance and the patients for participating in this study.

\section{References}

I. Morar N, Willis-Owen SA, Moffatt MF, Cookson WO: The genetics of atopic dermatitis. J Allergy Clin Immunol 2006, I I 8:24-34.

2. Simon D, Braathen LR, Simon HU: Eosinophils and atopic dermatitis. Allergy 2004, 59:56I-570.

3. Breuer K, Kapp A, Werfel T: Urine eosinophil protein X (EPX) is an in vitro parameter of inflammation in atopic dermatitis of the adult age. Allergy 200I, 56:780-784.

4. Pucci N, Lombardi E, Novembre E, Farina S, Bernardini R, Rossi E, Favilli T, Vierucci A: Urinary eosinophil protein $X$ and serum eosinophil cationic protein in infants and young children with atopic dermatitis: correlation with disease activity. J Allergy Clin Immunol 2000, 105:353-357.

5. Goto T, Morioka J, Inamura H, Yano M, Kodaira K, Igarashi Y, Abe S, Kurosawa M: Urinary Eosinophil-derived Neurotoxin Concentrations in Patients with Atopic Dermatitis: A Useful Clinical Marker for Disease Activity. Allergol Int 2007, 56:433-438.

6. Czech W, Krutmann J, Schopf E, Kapp A: Serum eosinophil cationic protein (ECP) is a sensitive measure for disease activity in atopic dermatitis. Br J Dermatol 1992, I26:35 I-355. 
7. Jonsson UB, Bystrom J, Stalenheim G, Venge P: Polymorphism of the eosinophil cationic protein-gene is related to the expression of allergic symptoms. Clin Exp Allergy 2002, 32:1092-1095.

8. Jonsson UB, Bystrom J, Stalenheim G, Venge P: A (G->C) transversion in the 3' UTR of the human ECP (eosinophil cationic protein) gene correlates to the cellular content of ECP. J Leukoc Biol 2006, 79:846-85I.

9. Munthe-Kaas MC, Gerritsen J, Carlsen KH, Undlien D, Egeland T, Skinningsrud B, Torres T, Carlsen KL: Eosinophil cationic protein (ECP) polymorphisms and association with asthma, s-ECP levels and related phenotypes. Allergy 2007, 62:429-436.

10. Kim YJ, Kumaraswami V, Choi E, Mu J, Follmann DA, Zimmerman P, Nutman TB: Genetic polymorphisms of eosinophil-derived neurotoxin and eosinophil cationic protein in tropical pulmonary eosinophilia. Am J Trop Med Hyg 2005, 73: I25-130.

11. Hanifin JM, Rajka G: Diagnostic features of atopic dermatitis. Acta Derm Venereol 1980, 92:44-7.

12. Bel EH: Clinical phenotypes of asthma. Curr Opin Pulm Med 2004, 10:44-50.

13. De Marco R, Locatelli F, Cerveri I, Bugiani M, Marinoni A, Giammanco $G$ : Incidence and remission of asthma: a retrospective study on the natural history of asthma in Italy. J Allergy Clin Immunol 2002, I 1 0:228-235.

14. DeFinetti program [http://ihg.gsf.de/cgi-bin/hw/hwal.pl]

15. Genetic Power Calculator [http://pngu.mgh.harvard.edu/ pur cell/gpc/cc2.html]

16. Hoffjan S, Epplen JT: The genetics of atopic dermatitis: recent findings and future options. J Mol Med 2005, 83:682-692.

17. Cookson WO, Ubhi B, Lawrence R, Abecasis GR, Walley AJ, Cox HE Coleman R, Leaves NI, Trembath RC, Moffatt MF, et al.: Genetic linkage of childhood atopic dermatitis to psoriasis susceptibility loci. Nat Genet 200I, 27:372-373.

18. Bradley M, Soderhall C, Luthman H, Wahlgren CF, Kockum I, Nordenskjold M: Susceptibility loci for atopic dermatitis on chromosomes 3, 13, 15, 17 and 18 in a Swedish population. Hum Mol Genet 2002, I I:1539-1548.

Publish with Bio Med Central and every scientist can read your work free of charge

"BioMed Central will be the most significant development for disseminating the results of biomedical research in our lifetime. "

Sir Paul Nurse, Cancer Research UK

Your research papers will be:

- available free of charge to the entire biomedical community

- peer reviewed and published immediately upon acceptance

- cited in PubMed and archived on PubMed Central

- yours - you keep the copyright
BiolMedcentral 